\title{
Ethnocultural Information In Studying Russian As Foreign Language
}

\author{
D. Ilyin \\ Department of Russian Language and Document Studies \\ Federal State Autonomous Educational Institution of Higher Education, Volgograd State University \\ Volgograd, Russia \\ dilyin@volsu.ru
}

\begin{abstract}
This article studies the problems of teaching lexis and reading to foreign students with the help of ethnicallyfocused language material. It provides examples of toponymic names of Volgograd Oblast, which have emerged due to various intralinguistic and extralinguistic factors, provides linguistical, historical and cultural information, demonstrates how toponymic meaning aspects represent the mental component and distinguishes ethnocultural information as a system of knowledge, perception and evaluation describing the external world.
\end{abstract}

Keywords - lexis; onomastics; toponym; reading education; language development factors; ethnocultural information.

For teaching a foreign audience to read in Russian, the faculty members must emphasize the richness and diversity of Russian lexis and the openness of the lexical system. Meanwhile, studying the lexis means not only learning new words, but more importantly, understanding the semantic relations in the language, which are connected to the grammar: "Communicativeness requires getting and practicing new words in sentences and situations; there is no need to learn words separately, i.e. isolated from the meaningful whole" [1, p. 80]. The local, regional elements, if added to the lexical material, complicate the perception of Russian vocabulary, but at the same time provide foreign language speakers with the opportunity to understand the invariables of Russian history, the diversity of Russian culture with all its pathways and polyphony, thus corresponding to all educational components, which are understood as "the pedagogically adjusted system of expertise, knowledge, skills, creative activities, emotional and value-based worldview, that should be adopted for personal development" [2, p. 17].

Learning toponyms, which are typical for a certain territory, is of special interest to foreign students. Let us define the regional toponymicon as the "total amount of lexemes used for naming geographic objects of this region and, taking into account the local specifics, having a semantic and meaning potential, implemented through their functioning" [3, p. 64]. Volgograd Oblast is the territory of late settlement, and its toponymic names are a significant cultural phenomenon demonstrating the mentality of the local people, with all its specifics and uniqueness. Being the products of ethnic consciousness, toponyms as language signs enable to explicate various aspect of spiritual and material life. The results of linguistic analysis of onomastic data, supported by general historical information, make it possible to explain the local names and give additional information on the development of the language as a way of expressing the people's experience during a certain historical period: "Russian toponymics can become the basis for reconstructing typical geographical and cultural features of the region, which are included in the "toponymic vision", i.e. they may be represented in the local substrate names" [4, p. 48].

The regional material, which is used for including ethnocultural information in the educational process, allows foreign students to focus on understanding common and localized processes in the modern Russian standard language. For teaching the lexis to foreign language speakers, it is essential to take into account the temporal and geographical determinants of text production and correlation between common and regional language features in texts produced by local residents. The methods of language material analysis enable one to describe the language of a certain region, and in particular, distinguish the patterns for creating a toponymicon of a certain territory. This is why much attention is paid to the national and cultural peculiarities of geographic names of a region in relation to the linguistic knowledge and the information, which "is not strictly scientific, but instead belongs to the common knowledge" [5, p. 7].

Newspaper articles provide various information on geographic names and their usage, because the media language "is the factor, which has always had a great impact on the spiritual development of the society" [6, p. 21]. For analyzing the toponymic units functioning in the regional language, the authors have used the factual data from the regional newspaper Volgogradskaya Pravda (hereinafter - VP, with the date of issue indicated), which provides the most correct representation of local geographic names.

For an ethnic-focused approach to teaching foreign students to read, it is essential to demonstrate that the most typical names are based on nature- or geography-determined factors. For example, among the names meaning "administrative territorial units, cities and other inhabited localities", specific propriative lexis mentioned in the newspaper is represented by 2 settlements and 3 khutors named Stepnoy, which name is derived from the lexical unit 
"steppe" meaning "a vast, unforested, plain, grassy area in the arid climate zone" [7, vol. 4, p. 262]: The celebration took place on the Librarian Day, with a visit taken to the House of Culture of Stepnoy settlement, Leninsky District (VP, June 24, 2003); Last Monday, in Bykovsky District, a 25-year-old woman from Stepnoy khutor was driving a VAZ-2121 (VP, July 8, 2004).

Syntagmatic relations between onomastic and common lexis must be taken into consideration during the teaching process. Thus, toponymic units, which are parts of names with the meaning "water spaces, waterbodies", may be etymologically derived from the names of the local settlements. For instance, the toponyms taken from the following sentences: For many years the Aksai Yesaulovsky, with its bright waters babbling, has been meandering through the vast Don steppes (VP, September 9, 1998); according to the estimates, the water from the Don should have reached the suburbs through the bed of the Aksai Kurmoyarsky and made the river navigable (VP, October 31, 1998). The lexical units like babbling and water, related to the onyms, allow us to identify the geographic objects as waterbodies. The contextual element babbling from the first sentence has the meaning "producing a monotonous babbling sound, noise (flowing water)" [7, vol. 1, p. 489], thus giving the opportunity to classify this waterbody as a constant waterflow with a natural current, i.e. a river.

The Aksai Yesaulovsky and the Aksai Kurmoyarsky hydronyms have different limiting attributes, derived from the names of Yesaulovskaya, Verkhnekurmoyarskaya and Nizhnekurmoyarskaya stanitsas. The etymological analysis of the lexeme "Yesaulovsky" gives the reasons to suggest that this onym derived from the name of a stanitsa, located near the river bed and named after the word yesaul meaning "in the Tsarist army: a Cossack military rank, equal to infantry captain; the person holding this rank" [7, vol. 1, p. 467], thus indicating there was a Cossack settlement on this territory.

The combination of history and lexis studies is based on the idea that onyms may serve not only as names of specific regional objects, but also as "a distinctive and significant attribute of a certain ethnic group" [8, p. 10]. Due to their semiotic nature, toponyms as language units are determined by the obligatory presence of background knowledge in the structure of their meaning. E.M. Vereshagin and V.G. Kostomarov, distinguishing the national and cultural component of the meaning structure, claim this component to be "typical for proper nouns; perhaps, even to a greater extent than for common nouns" [4, p. 56]. Besides, for any person a certain geographic name is connected to a certain place and time period. This spatial distribution of toponyms allows them to be representatives and keepers of significant cultural data. The toponymic lexis formation is influenced by the factor of geographic names historicity, because every name could be explained judging from its origin. Propriatives include those named because of historical reasons. For example, toponym groups with the meaning "administrative territorial units, cities and other inhabited localities" may indicate the history of toponym formation: Novaya Poltavka village, Kievka khutor, Kharkovka village indicate that the first residents of these settlements came from the Ukraine, because the root morphemes structure of these onyms corresponds to the names of Ukrainian cities: Poltava, Kiev, Kharkov; this could be verified by newspaper articles from different time periods: Kharkovka village flooded in spring (VP, April 12, 1999).

For studying lexis, foreign language speakers must realize that national and cultural specifics of a region are represented in toponymic units, which names are determined by historical events or people. Such geographic proper nouns in the communication space of Volgograd Oblast are present only as a part of a toponymic group meaning "administrative territorial units, cities and other inhabited localities". In particular, such names are related to the previous regimes and belong to the so-called "Sovietisms" [5, p. 104], e.g. Krasny Pakhar settlement (Red Plowman), Bolshevik settlement, imeni XIX partsyezda settlement (named after the 19th Congress of the Party), Kolkhoznaya Akhtuba village (Akhtuba Collective Farming). This fact is represented in newspaper articles: A small, but precious gift was given to the residents of the Southeastern part of Velikiy Oktyabr settlement (the Great October) (VP, May 11, 2002).

The social reasons for using a toponym are represented only in case of names meaning "administrative territorial units, cities and other inhabited localities". The renaming of geographical objects in the 1920-30s is a perfect example of such cases. For instance, in 1919 Prishib village was renamed Leninsk town after the Bolshevik leader; in 1933 UstMedveditskaya Cossack stanitsa became Serafimovich town, named after A. Serafimovich, the Soviet writer who had been born there. In 1936, Preobrazhenskaya Cossack stanitsa was renamed Kikvidze working settlement in memory of Vasily Kikvidze, the Russian Civil War participant and the division commander, who fought against the White Army Cossacks in the Don region. However, in 1999 the settlement got back its original name - Preobrazhenskaya. The abovementioned toponymic units can be found in media articles: The artists were awaited in Ust-Medveditskaya (Serafimovich). The people of Ust-Medveditskaya cannot forgive the former resident for making a monument to himself in his lifetime and depriving the stanitsa of its original name (VP, October 1, 1998), ...Even in 1987 a pipeline was put into operation, connecting Novonikolayevsky and Preobrazhenskaya stanitsa (back then, the stanitsa was named Kikvidze working settlement) (VP, November 11, 1998).

The national and cultural aspect of toponymic semantics is characterized by a special regional geography representativeness because the evaluation of the objects characterized by toponyms determines the role of geographic names in the main wordstock of the language. From the viewpoint of geographical objects significance, in Volgograd Oblast small inhabited localities are prevailing, such as khutors, stanitsas, etc., which residents, due to their lifestyle, have a conservative opinion on settlement name and oppose to any renaming. Thus, despite the change in the social and political situation, many names, which reflect Soviet ideology or famous persons, remain unchanged, for instance: The pipeline in Ust-Buzulukskaya stanitsa is under renovation, Krasny Oktyabr (Red October) settlement is on the list (VP, October 13, 2004). 
In case foreign students are taught to read within the framework of lexis representation, they are able to realize that the ethnocultural dependency of onyms can be clearly seen in the names meaning "administrative territorial units, cities and other inhabited localities". In Volgograd Oblast, with its Cossack population, the emergence and functioning of onyms derived from the noun "kazak" (Cossack) seem logical, with the noun meaning "a representative of a military strata, which was formed in the 15-17 centuries on the Russian frontiers by the free people, and which had to do military service for land usage bonuses since the 18th century" [7, vol. 2, p. 13]: Kazachiy khutor, stanitsa Kazachka. Among names meaning "water spaces, waterbodies", the ethnocultural dependency can be determined by dialect definitions taken from the common noun lexis: Lake Kuzhnoye was named after kuga, a name that the locals had for a certain swamp plant. The Sokarka River was named after sokar, the dialect name of a poplar. The group of onyms with the meaning "landscape, natural formations" reflects the Cossack habits: e.g. Pyany (Drunken) hill got its name because next to it, the Cossacks, newly recruited to the army, drank their last cup before leaving.

Thus, Volgograd Oblast toponyms are, in a way, the "guardians" of historical and cultural data. In particular, it is known that this territory is the area of late settlement, formerly populated by nomads. In order to emphasize the special status of the Russian population, the local residents gave the settlements names containing the word "russkiy" (Russian), and these names remain even nowadays: Poeticheskaya (Poetic) Osipovka was divided, thanks to the German settlers, into Russkaya (Russian) Osipovka and Nemetskaya (German) Osipovka and currently has 20 households at most, having lost, obviously, Nemetskaya Osipovka (VP, June 16, 2004).

On the map of Volgograd Oblast, there are geographic objects named basing on the so-called folk etymology, which can be demonstrated by a waterbody etymology. For instance, according to the legend, the Akhtuba River hydronym, belonging to the "water spaces, waterbodies" group, was named after a khan's daughter, who had thrown herself in the river. In the local newspaper, the usage of this hydronym is not related to this legend: A more distant project that one can think on is a small hydro power plant with 14 turbines on the Akhtuba River. (VP, April 2, 2002).

Teaching lexis and reading assumes including well-known toponymic names to the educational materials. Social factors may change the way local language speakers perceive a geographic name. For example, a town named Uryupinsk has been subject to such transformation. Due to the traditions of its native Cossack residents, famous handicraft, i.e. products made of goat wool and fluff, and a cultural revival of various local ethnic groups, Uryupinsk is mentioned in the media as the center of Russian province, a "small motherland": "A holiday atmosphere of the upcoming New Year is all over Uryupinsk, the unofficial capital of Russian province" (VP, December 26, 2002). The name "Uryupinsk" is often used figuratively to describe a place far from any civilization "backwater, the middle of nowhere" [9, p. 372]: Give it all up and go to Uryupinsk (VP, 26.06.2003). Finally, the oikonym Uryupinsk is a symbolic designation of a place with advanced goat fluff handicraft. Meanwhile, more than 100 contestants gather in Uryupinsk, the fluff capital of Russia (VP, September 25, 2003). The goat, a traditional Cossack animal, is currently associated with the image of this inhabited locality.

Thus, the analysis of onomastic units used in a region enables one to demonstrate the aspects of their meaning in relation to the mental component, basing on structural and functional toponymic aspects. Besides, the analysis presents the ethnocultural information as a system of knowledge, perception and evaluation describing the external world; this gives an opportunity to represent properly the language material in the process of teaching lexis and reading to foreign students.

\section{Acknowledgment}

The article was prepared with the financial support of the Department of Humanities and Social Sciences of the Russian Foundation for Basic Research and Volgograd Region Administration under the science project No. 17-14-34005.

\section{References}

[1] V.G. Kostomarov, O.D. Mitrofanova, Methodological textbook for teaching Russian as a foreign language, 4th ed., rev. Moscow: Russkiy Yazyk, 1988. (in Russian).

[2] T.M. Balykhina, Structure and content of Russian philological education. Methodological problems of Russian language studies, Moscow: Moscow State University of Printing Arts Publishing, 2000. (in Russian).

[3] D.Y. Ilyin, Toponymic lexis in regional newspaper articles of late 19thearly 21st centuries, Volgograd: Volgograd State University Publishing, 2012. (in Russian).

[4] N.V. Kabinina, "Semantic modeling and problems of etymologizing regional toponymic substrate (on Arkhangelsk Pomor territory toponyms," Bulletin of the Russian Academy of Sciences: Studies in Literature and Language, vol. 68, No. 2, pp. 48-53, 2009.

[5] E.M. Vereshagin, V.G. Kostomarov, Linguistic and cultural studies in teaching Russian as a foreign language, Moscow: Nauka, 1991. (in Russian).

[6] N.E. Petrova, L.V. Ratsiburskaya, Modern Media Language: Means of Verbal Aggression, Moscow: Flinta:Nauka, 2011. (in Russian).

[7] Russian Language Dictionary: in 4 vol., ed. by A.E. Evgenyeva, vol. 14, Moscow: Russkiy Yazyk, 1980-1984. (in Russian).

[8] V.I. Suprun, Onomastic field of Russian language and its cultural and aesthetic potential, Volgograd: Peremena, 2000. (in Russian).

[9] E.S. Otin, Connotative proper nouns dictionary, Moscow: A Temp, 2006. (in Russian). 